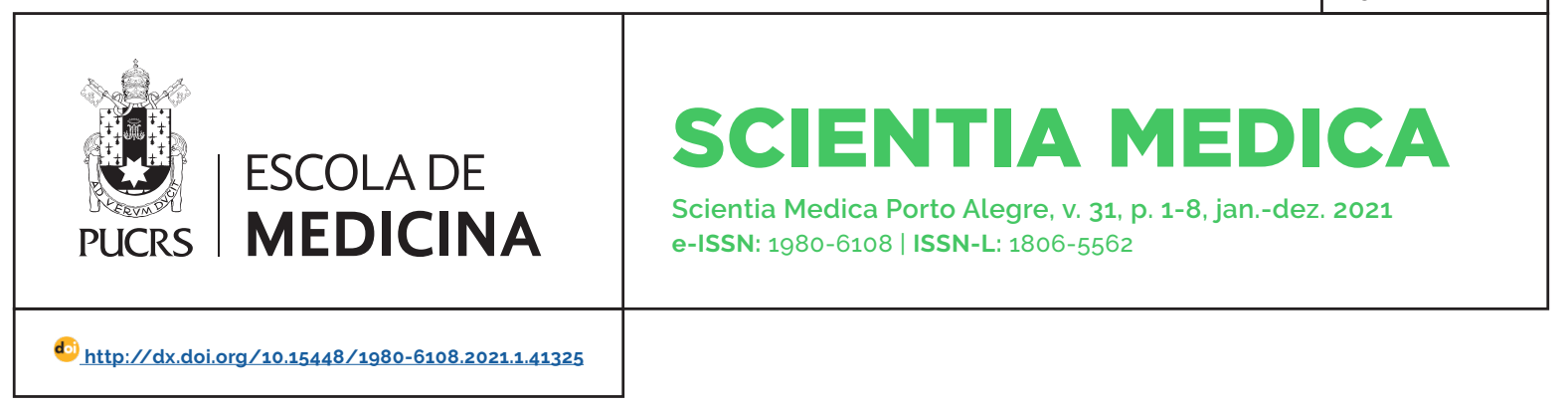

RESEARCH ARTICLE

\title{
Anti-Staphylococcus aureus Methicillin-Resistant (MRSA) Activity of a Novel 3-Chalcogenyl Indole
}

\author{
Atividade Anti-Staphylococcus aureus Meticilina Resistente (MRSA) de um novo \\ composto 3-Calcogenil Indol
}

\author{
Laisa Borges Ferreira ${ }^{1}$ \\ orcid.org/0000-0003-4005-4364 \\ laisaborgesf@gmail.com
}

Edilma Elayne da Silva ${ }^{1}$

orcid.org/0000-0002-2905-6054

edilmaelayne@gmail.com

Silvia Adriana Meyer Lentz ${ }^{1}$ orcid.org/0000-0002-0118-6797

silvia82drica@gmail.com

Juliano Braun de Azeredo ${ }^{1}$ orcid.org/0000-0001-6277-0754 jbraunquimico@gmail.com

\section{Antonio Luiz Braga ${ }^{1}$ \\ orcid.org/0000-0001-9903-6764 silvia82drica@gmail.com}

\section{Michel Mansur Machado ${ }^{1}$}

orcid.org/0000-0002-7583-9332

michelmachado@unipampa.edu.br

Mario Lettieri Teixeiraz ${ }^{1}$ orcid.org/0000-0003-4546-5584 mario.lettieri@gmail.com

Juliana Caierão ${ }^{1}$

orcid.org/0000-0002-8776-8447

juliana.caierao@ufrgs.br

\section{Gustavo Pozza Silveira ${ }^{1}$}

https://orcid.org/0000-0001-8539-2610

gustavo.silveira@iq.ufrgs.br

\section{Andreza Francisco Martins ${ }^{1}$}

https://orcid.org/0000-0001-6227-1920 andrezafm20@gmail.com

Received on: Apr.2 $2^{\text {nd }}, 2021$

Approved on: Nov. $3^{\text {nd }}, 2021$.

Published on: Dec. 20 ${ }^{\text {th }}, 2021$.

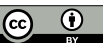

Artigo está licenciado sob forma de uma licença Creative Commons Atribuição 4.0 Internacional

\begin{abstract}
Objective: the development of new drugs against Methicillin-resistant Staphylococcus aureus is a priority to the World Health Organization. So, the objective of this study was to evaluate the antibacterial activity and toxicity of 5-bromo-3-((4-methoxyphenyl) sulfenyl)- $1 \mathrm{H}$-indole (3b) against MRSA.

Methods: minimum inhibitory concentration (MIC) of $3 \mathrm{~b}$ was determined against S. aureus ATCC 29213 and 43 clinical isolates. The time-kill assay was performed for 9 isolates. Analysis of variance followed by the post hoc Bonferroni test was used for the statistical tests.

Results and conclusions: the $\mathrm{MIC}_{50}$ and $\mathrm{MIC}_{90}$ of $3 \mathrm{~b}$ were $4 \mu \mathrm{g} \cdot \mathrm{mL}-1$ and 16 $\mu \mathrm{g} \cdot \mathrm{mL}^{-1}$ respectively. In time-kill assay, the $3 \mathrm{~b}$ showed bactericidal activity to all evaluated isolates at concentrations of $1 \times \mathrm{MIC}$ and $2 \times \mathrm{MIC}$ and the re-growth effect was not observed. About the toxicity tests, $3 \mathrm{~b}$ has not presented cytotoxicity, mutagenicity, or allergenicity. 3b had particularly good activity against MRSA demonstrating high potential for the development of new antimicrobials products.
\end{abstract}

Keywords: anti-MRSA, chalcogenyl-indoles, new antimicrobials, time-kill, Staphylococcus aureus.

\section{Resumo}

Objetivo: o desenvolvimento de novos antimicrobianos contra Staphylococcus aureus resistentes à meticilina (MRSA) é uma prioridade para a Organização Mundial da Saúde. Então, o objetivo desse estudo foi avaliar a atividade antibacteriana e a toxicidade do 5-bromo-3-((4-metoxifenil) sulfenil)- $1 \mathrm{H}$-indol (3b) contra MRSA.

Métodos: a concentração inibitória minima de $3 b$ foi determinada contra $S$. aureus ATCC 29213 e 43 isolados clinicos. O ensaio de curva de morte foi realizado para nove isolados. Análise de variância seguida pelo teste post hoc Bonferroni foi usada para testes estatísticos.

Resultados e conclusões: a $\mathrm{MIC}_{50}$ e $\mathrm{MIC}_{90}$ do $3 \mathrm{~b}$ foi $4 \mu \mathrm{g} \cdot \mathrm{mL}^{-1}$ e $16 \mu \mathrm{g} \cdot \mathrm{mL}^{-1}$, respectivamente. No ensaio de curva de morte, o $3 \mathrm{~b}$ demonstrou atividade bactericida contra todos os isolados avaliados na concentração de 1XMIC e 2xMIC e o recrescimento não foi observado. Em relação aos testes de toxicidade, 3b não apresentou citotoxicidade, mutagenicidade ou alergenicidade. 3b apresentou atividade particularmente interessante contra MRSA, demonstrando alto potencial para o desenvolvimento de novos produtos antimicrobianos.

\footnotetext{
1 Federal University of Rio Grande do Sul (UFRGS).
} 
Palavras-chave: anti-MRSA, chalcogenil-indóis, novos antimicrobianos, ensaios de curva de morte, Staphylococcus aureus.

ABBREVIATIONS: 3b, 5-bromo-3-((4-methoxyphenyl) sulfenyl)-1H-indole; ATCC, american type culture collection; CFU, colony forming unit; dimethylsulfoxide; MIC, minimal inhibitory concentration; MRSA, methicillin-resistant Staphylococcus aureus.

\section{Introduction}

The excessive use of antimicrobials in human and veterinary medicine has increased the prevalence of resistant microorganisms, leading to therapeutic failure and high mortality rates. In this context, the World Health Organization has published a list of bacteria with epidemiological importance. This list included Methicillin-Resistant Staphylococcus aureus (MRSA) as a high-priority issue (1).

Meanwhile, the discovery of new classes of antimicrobials has undergone a gradual decline in recent decades due to difficulties to identify new natural or synthetic drugs with low toxicity and a relevant spectrum of antimicrobial properties, along with economic and legal concerns (2). One interesting approach in the discovery of new drugs is studying the "privileged scaffolds", which are structures that can interact with different molecular targets due to their appropriate molecular size. Substituents can be built into these structures and it allows the construction of libraries of highly diverse compounds 3 . Indoles are a well-known example of privileged scaffolds and several commercial drugs (including indomethacin, ondansetron, tadalafil, delavirdine among others) are indole derivatives. These drugs interact with a myriad of molecular targets (3).

Within our ongoing research program seeking new molecules with antimicrobial properties(4) for future in vivo studies, a library of 14 3-sulfenyl- and 3-selenyl-indoles were screened for antibacterial activity. The 5-bromo-3-((4-methoxyphenyl) sulfenyl)- $1 \mathrm{H}$-indole, here called $3 \mathrm{~b}$ (Figure 1) presented the most promising results in screening tests, especially against Staphylococcus spp. That is the reason why this study aimed to deeply evaluate the activity of $3 b$ against $S$. aureus, mainly MRSA strains.

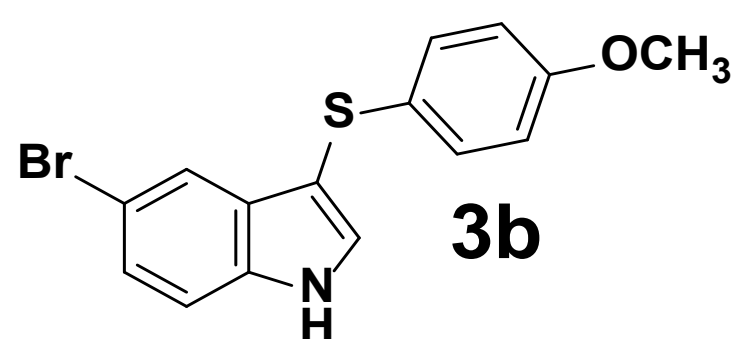

Figure 1 - Chemical structure of 5-bromo-3-((4-methoxyphenyl)sulfenyl)- $1 \mathrm{H}$-indole (3b).

\section{Matherial and Methods}

Study area

The study was developed at Applied Microbiology Laboratory (Federal University of Rio Grande do Sul) from March 2016 to March 2018.

\section{Experiments}

The preparation of $3 \mathrm{~b}$ was performed as previously described by Azeredo et al. (5). The crude product was purified by column chromatography by using a mixture of ethyl acetate/hexanes (20:80) as eluent. The compound was characterized based on the melting point (when solid) and infrared and ${ }^{1} \mathrm{H}$ and ${ }^{13} \mathrm{C}$ NMR spectra (5).

The microdilution broth was performed to determine the Minimal Inhibitory Concentration (MIC), according to the Clinical and Laboratory Standards Institute (6). The $3 \mathrm{~b}$ was prepared in $2 \%$ dimethylsulfoxide and diluted in Mueller-Hinton broth. The compound was tested in concentration ranged from 0.125 to $32 \mu \mathrm{g} \cdot \mathrm{ml}^{-1}$ against $S$. aureus ATCC 29213 and 43 clinical isolates of $S$. aureus (including $25 \mathrm{MRSA}$ ) from the library of Laboratory of Research in Bacterial Resistance (LABRESIS). The isolates were previously identified by matrix-assisted laser desorption/ionization time-of-flight mass spectrometry using the equipment of Bruker in its ion positive mode. The software BioTyper (Bruker, version 3.4) was used to analyze results.

Nine clinical isolates of S. aureus were selected according to their susceptibility profile for time-kill assay, which was performed as described by Isenberg (7) and following recommendations of Clinical and Laboratory Standards Institute (6). Bacterial inoculum 
was incubated at concentrations corresponding to $0.5 \mathrm{x}, 1 \mathrm{x}$, and $2 \mathrm{x}$ the MIC of $3 \mathrm{~b}$. Aliquots of $50 \mu \mathrm{L}$ were taken at $0,1,2,4,6,12$, and $24 \mathrm{~h}$. After serial dilutions, $20 \mu \mathrm{L}$ of each dilution was plated in mannitol salt agar and incubated for 18 to $24 \mathrm{~h}$ at $35^{\circ} \mathrm{C}$ for CFU counting. The assay was performed in duplicate.

The human leukocyte cultures were prepared according to the methodology described by Dos Santos et al. (8) to evaluate the genotoxicity and mutagenicity $(9,10)$. Phosphate buffered saline (PBS) $\mathrm{pH} 7.4$ was used as the negative control and $3 \mu \mathrm{M}$ bleomycin as the positive control. 3b was evaluated in a concentration of $32 \mathrm{\mu g} \mathrm{ml}^{-1}$. Cell cultures were incubated (5\% $\mathrm{CO}_{2}$, incubator model MCO19AIC, Sanyo) for $72 \mathrm{~h}$ at $37^{\circ} \mathrm{C}$. Cell viability was assessed with $0.2 \%$ trypan blue (Sigma-Aldrich), according to Burow et al (9). The Hen's Egg Test on the Chorioallantoic Membrane was used to allergenicity test (11).

Analysis of variance followed by the post hoc Bonferroni test was performed in the statistical analysis of toxicity test results. Results with $p<0.05$ were considered significant. Data were analyzed using the GraphPad PRISM version 5.02 software program. The assays were performed in duplicate.

\section{Results}

The most of the clinical isolates selected to time-kill assay were resistant to -lactams (MIC90: oxacillin $64 \mu \mathrm{g} \cdot \mathrm{mL}^{-1}$; Piperacillin + Tazobactam 16 $\mu \mathrm{g} \cdot \mathrm{mL}^{-1}$; Ceftriaxone $64 \mu \mathrm{g} \cdot \mathrm{mL}^{-1}$; Meropenem 16 $\mu \mathrm{g} \cdot \mathrm{mL}^{-1}$ ) and all of them were susceptible to levofloxacin, tigecycline, and vancomycin. The MIC of $3 \mathrm{~b}$ was $4 \mu \mathrm{g} \cdot \mathrm{mL}^{-1}$ for 4 isolates (including ATCC strain) and $8 \mu \mathrm{g} \cdot \mathrm{mL}^{-1}$ for the remaining 6 isolates.

Figure 2 presents the results of the time-kill assay. The $3 \mathrm{~b}$ demonstrated bactericidal activity (Log $\triangle$ CFU ml-1 > 3) for all isolates and ATCC 29213 strain at concentrations of $1 \times \mathrm{MIC}$ and $2 \times \mathrm{MIC}$. For control strain, S. aureus ATCC29213 the experiment was performed with oxacillin (Figure $2 \mathrm{~A}$ ) and with the $3 \mathrm{~b}$ (Figure $2 \mathrm{~B}$ ). Figures $2 \mathrm{C}-\mathrm{K}$ represent, the results of time-kill using $3 \mathrm{~b}$ for isolates 442,444 . 459, 460, 463, 467, 469, 480 and 487. Each figure shows the results of experiments with $1 / 2 x$ (blue line), $1 x$ (red line), and $2 x$ (green line) the MIC of $3 b$ for the isolate tested. 

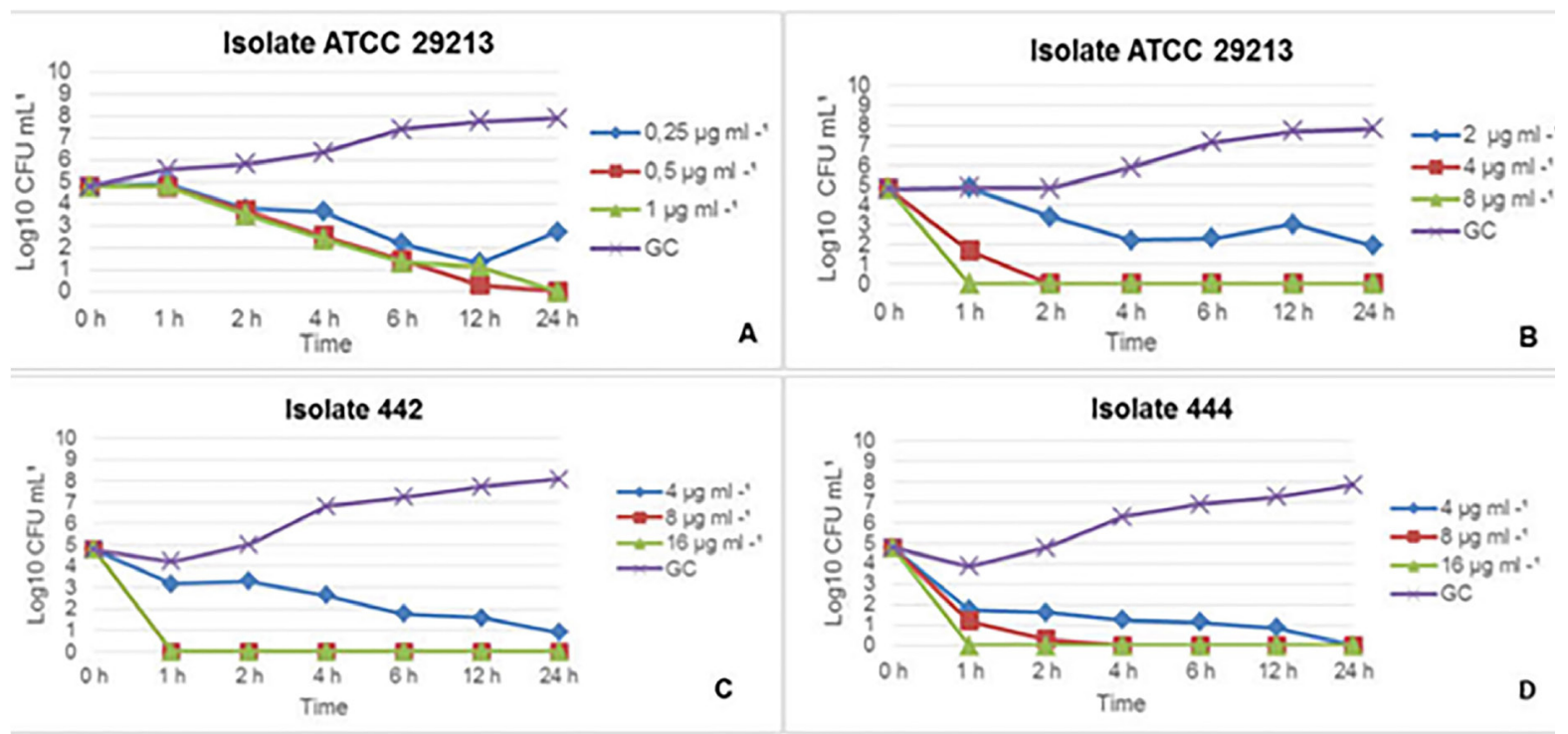

Isolate 459
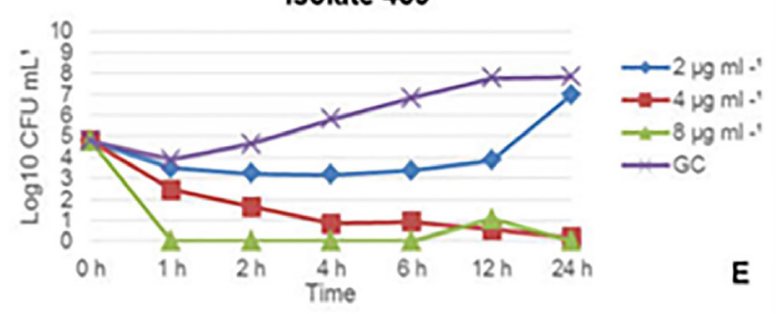

Isolate 460

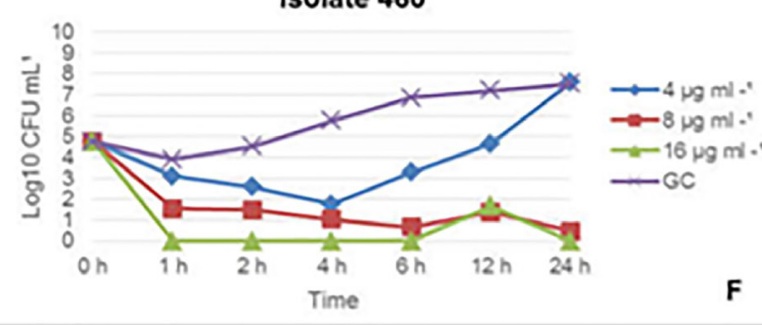

Isolate 463

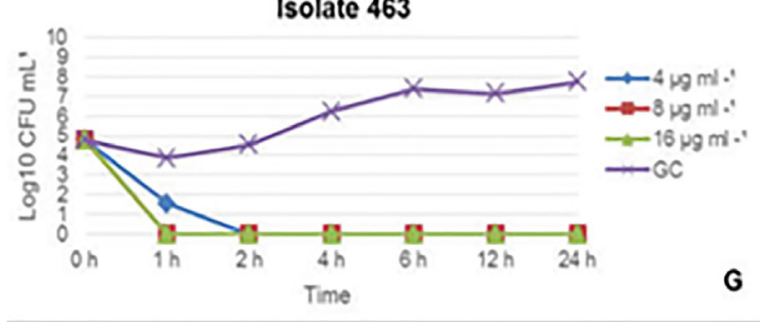

Isolate 467
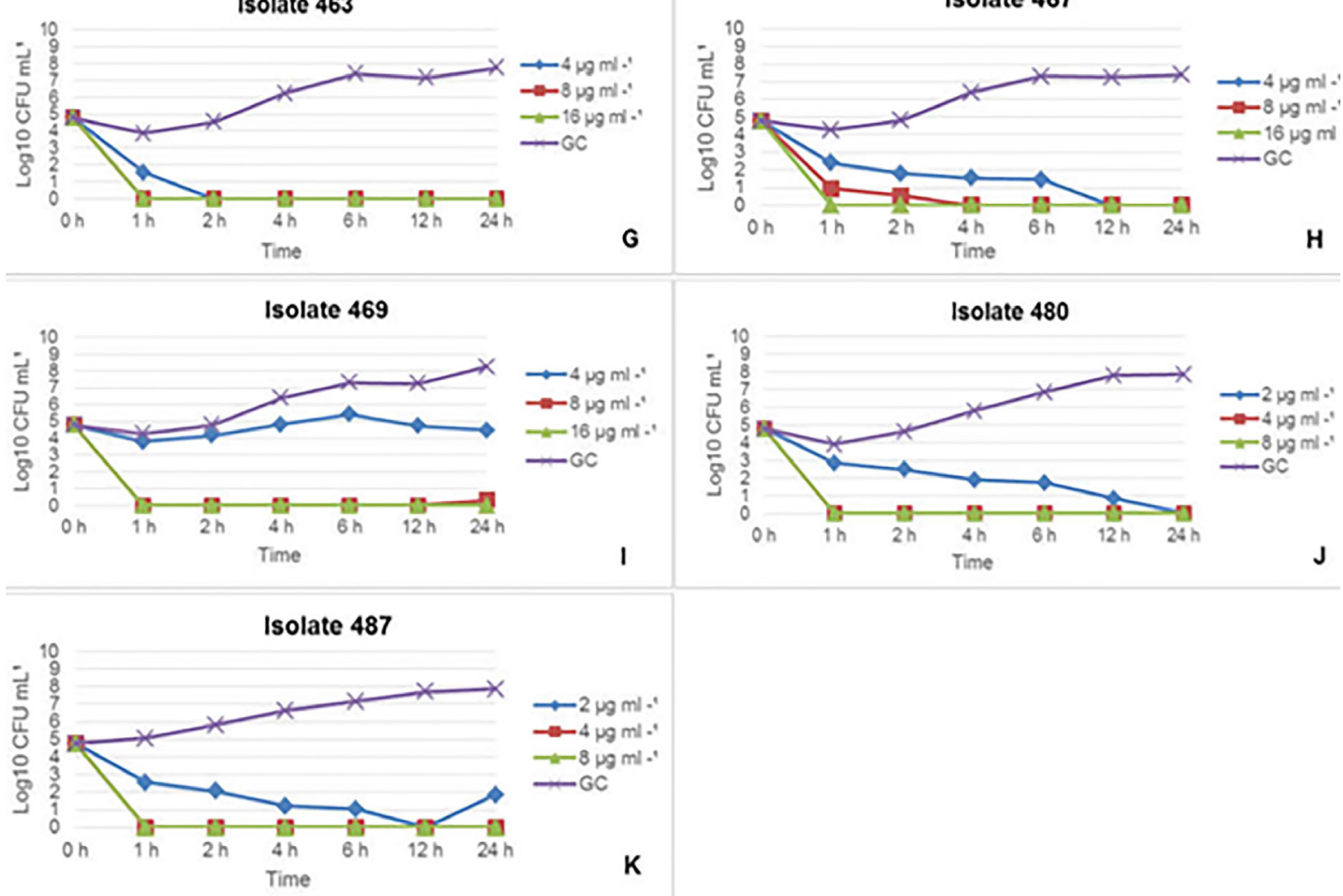

Figure 2 - Time-kill curves of oxacillin and compound 3 b for 9 clinical isolates and S. aureus (ATCC 29213). A: oxacilin. B-K: compound 3b. dots: 0.5x MIC; square: 1XMIC; triangle: 2XMIC; X: GC - growth control (growth of bacteria without any antibiotic at the medium). 
The bactericidal activity ( $L o g \triangle C F U \mathrm{ml}^{-1}>3$ ) against isolates $442,463,469,480$, and 487 at $1 \times M I C$ was observed in the first hour of incubation (Figure 2 C, G, I, and K), while for the isolates 444 and 467 the same effect was demonstrated after 4 h (Figure 2. $\mathrm{D}$ and $\mathrm{H}$ ). Compound 3b presented bactericidal activity toward the whole bacterial panel at 2xMIC after $1 \mathrm{~h}$ (Figure $2 \mathrm{~B}-\mathrm{K}$ ).

At subinhibitory concentrations (0.5xMIC), 3b was bactericidal against isolate 444 (after 24h), 467 (after 12h), 480 (after 24h), and 487 (after 12h) (Figure $2 \mathrm{D}, \mathrm{H}, \mathrm{J}$, and K). However, a re-growth of 487 was observed after $24 \mathrm{~h}$ of the experiment (Figure $2 \mathrm{~K}$ ).

When the bactericidal activities of oxacillin and 3b were compared, it was observed that the oxacillin colony count reduced to zero after $12 \mathrm{~h}$ and $24 \mathrm{~h}$ for S. aureus ATCC 29213 strain at 1XMIC and 2XMIC, respectively (Figure $2 A$ ) while compound $3 b$ had the same effect after $4 \mathrm{~h}$ at $1 \times \mathrm{MIC}$ and $1 \mathrm{~h}$ at $2 \mathrm{XMIC}$ (Figure $2 \mathrm{~A}$ and B). Besides, re-growth of the ATCC strain in the presence of oxacillin at 0.5XMIC was observed after $12 \mathrm{~h}$. This behavior was not observed in the presence of $3 \mathrm{~b}$ (Figure $2 \mathrm{~A}$ vs Figure $2 \mathrm{~B}$ ).

The viability of human leukocytes was approximately $98 \%$ in the presence of $3 b$ and $100 \%$ with PBS (negative control). The $3 \mathrm{~b}\left(32 \mu \mathrm{g} \cdot \mathrm{ml}^{-1}\right)$ caused an increase in DNA strand breaks, which were $173 \pm 8.02 \%$ ( $p<0.05$ ) higher than PBS (negative control) but did not cause cell apoptosis or necrosis. Results obtained from the micronucleus test (mutagenicity) were evaluated using Fenech's cytotoxicity index, also known as the nuclear division index. The $3 b$ showed an nuclear division index of $0.03 \pm 0.02$ ( $p$ $<0.05)$, which is similar to the value obtained for PBS (negative control). The nuclear division index for the $3 \mathrm{mM}$ bleomycin (positive control) was $0.31 \pm 0.03$ ( $p$ $<0.05)$. In the allergenicity evaluation, the irritancy score (IS) was 3.47, while 0.1M sodium hydroxide (positive control) showed an irritancy score of 19.9. Thus, 3b was non-irritant, non-mutagenic, and non-cytotoxic according to our assays.

\section{Discussion}

Indole compounds are interesting privileged scaffolds molecules explored for different activities in human medicine. Cruz-Muñiz and co-workers demonstrated that several compounds as 3-methoxyphenyl-5-bromo-indole that present anti-cancer activity also has antimicrobial potential (12). Therefore, our group previously evaluated a library of 14 3-chalcogenyl indoles against ATCC strains, including Gram-positive cocci and Gram-negative bacilli. The most promising results were observed for the compound 3b, which encouraged us to increment antibacterial activity evaluation. The $3 \mathrm{~b}$ has a substituent at the para position of the phenyl ring, which seems to be important for the Gram-positive spectrum of action since other indole derivatives without this characteristic did not show activity against Gram-positive at all.

Many studies have been published that showed the antimicrobial activity of the indole derivates. Most of them reported activity against gram-positive bacteria (13-15) including MRSA.

On the other hand, some authors identifying analogs with enhanced antibacterial activity towards gram-negative bacteria and fungi $(13,15,16)$ However, although all of the compounds are indole derivatives, there are variations in the molecules that can alter their activity $(16,17)$.

To the best of our knowledge, this is the first study that evaluated the antibacterial activity of $3 \mathrm{~b}$ against MRSA. The $3 \mathrm{~b}$ caused full growth inhibition of several clinical isolates at 1 XMIC and 2XMIC. This compound also had a bactericidal effect, which was maintained throughout the experiment (Figure 2). Interestingly, 3b was more active than oxacillin against S. aureus ATCC 29213 and showed a bactericidal effect against all clinical MRSA isolates. Daly et al (14). have found similar results when they have evaluated the 2,3 Disubstituted indoles against MRSA. Compound $3 \mathrm{~b}$ demonstrated no evidence of cytotoxicity, mutagenicity, or mucous irritancy, but seems to present low genotoxicity. Nevertheless, the $3 \mathrm{~b}$ did not cause cell apoptosis or necrosis as have been reported for other indole derivates. Although there can be restrictions on the use of $3 \mathrm{~b}$ in oral formulations due to its genotoxicity, the application as an antiseptic, disinfectant and antibiofilm can be promising since medical devices are susceptible to $S$. aureus colonization. 
Over the last decade, there has been a considerable focus on the prevention of health-associated infections, including those caused by MRSA. Most clinical isolates included in this study were characterized as MRSA and presented resistance to at least 3 different classes of antimicrobials analyzed, which defines them as multidrug-resistant. This scenario is quite similar to what is commonly found in many health institutions in Brazil and around the world (18).

Several authors have reported that preventive measures, such as the use of antiseptic agents for hand hygiene, besides the use of mupirocin and fusidic acid, combined or not with oral vancomycin for skin decolonization before invasive procedures, can reduce the risk of MRSA infections (19). However, bacterial resistance to these topical antibiotics highlights that the discovery and development of new antibacterial agents are urgently required.

\section{Conclusion}

In this study, we demonstrated that $3 b$ had a very good antibacterial activity against MRSA without re-growth in vitro. Besides that, it was not cytotoxic, mutagenic, and irritant. Therefore, the results obtained in this study suggested that 3-chalcogenyl indoles are promising candidates that merit further study.

\section{Notes}

Acknowledgments: Laboratory of Research in Bacterial Resistance (LABRESIS) of the Hospital de Clínicas of Porto Alegre.

\section{Funding}

This study received financial support from FAPERGS (PRONUPEQ 2016), CAPES.

\section{Conflicts of interest disclosure}

The authors declare no competing interests relevant to the content of this study.

\section{Authors' contributions}

All the authors declare to have made substantial contributions to the conception, or design, or acquisition, or analysis, or interpretation of data; and drafting the work or revising it critically for important intellectual content; and to approve the version to be published.

\section{Availability of data and responsibility for the results}

All the authors declare to have had full access to the available data and they assume full responsibility for the integrity of these results.

\section{References}

1. Word Heath Organization. Global priority list of antibiotic-resistant bacteria to guide research, discovery, and development of new antibiotics [Internet]; 2017 [cited 2017 Nov 20]. Available from: http://www.who. int/medicines/publications/global-prioty-list-antibiotic-resistant-bacteria

2. Moellering RC. Discovering new antimicrobial agents. Int J Antimicrob Agents. 2011;37(1):2-9. https://doi.org/10.1016/j.ijantimicag.2010.08.018

3. Welsch ME, Snyder, Stockwell BR. Privileged scaffolds for library design and drug Discovery. Curr Opin Chem Bio. 2010;14(3):347-61. https://doi.org/10.1016/j. cbpa.2010.02.018

4. Batista BG, Lana DFD, Silveira GP, Sá MM, Ferreira M, Russo TVC, et al. Allylic selenocyanate as new agents to combat Fusarium species involved with human infections. Chemistry Select. 2017;2(35):11926-32. https:// doi.org/10.1002/slct.201702338

5. Azeredo JB, Godoi M, Martins GM, Silveira CC, Braga AL. A solvent- and metal-free synthesis of 3-Chacogenyl-indoles employing DMSO $/ \mathrm{I}_{2}$ as an eco-friendly catalytic oxidation system. J Org Chem. 2014:79(9):412550. https://doi.org/10.1021/j05000779

6. Clinical and Laboratory Standards Institute (CLSI). Performance standards for antimicrobial susceptibility. Twenty-second Information Supplement. CLSI document M100-S25 [Internet]. Wayne, PA: Clinical and Laboratory Standards Institute; 2015 lupdated 2018 Jan 24l. Available from: https://clsi.org/standards/ products/free-resources/access-our-free-resources

7. Isenberg HD. Clinical Microbiology Procedures Handbook (American S). editor in chief. Washington, D.C: American Society of Microbiology; 1992. p. 12.

8. Montagner GFMS, Sagrillo M, Machado MM, Almeida RC, Mostardeiro CP, Duarte MMMF, et al. Toxicological effects of ultraviolet radiation on lymphocyte cells with different manganese superoxide dismutase Ala16Val polymorphism genotypes. Toxicology in Vitro. 2010;24(5):1410-6. https://doi.org/10.1016/j. tiv.2010.04.010 
9. Burow ME, Weldon CB, Tang Y, et al. Differences in susceptibility to tumor necrosis factor-induced apoptosis among MCF-7 breast cancer cell variants. Cancer Res. 1998;58(21):4940-6.

10. Singh NP, McCoy MT, Tice RR, Schneider EL A simple technique for quantitation of low levels of DNA damage in individual cells. Exp Cell Res. 1988;175(1):184-91. https://doi.org/10.1016/0014-4827(88)90265-0

11. Jacobsen ID, Grosse K, Slesiona S, Hube B, Berndt A. Brock M. Embryonated eggs as an alternative infection model to investigate Aspergillus fumigatus virulence. Infect Immun. 2010;78(7):2995-3006. https:// doi.org/10.1128/|Al.00268-10

12. Cruz-Muñiz MY, López-Jacome LE, Hernández-Durán M, Franco-Cendejas R, Licona-Limón P, Ramos-Balderas JL, et al. Repurposing the anticancer drug mitomycin $\mathrm{C}$ for the treatment of persistent Acinetobacter baumannii infections. Int J Antimicrob Agents. 2017;49(1):88-92. https://doi.org/10.1016/j.ijantimicag.2016.08.022

13. Li SA, Cadelis MM, Sue K, Blanchet M, Vidal N, Brunel JM, et al. 6-Bromoindolglyoxylamido derivatives as antimicrobial agents and antibiotic enhancers. Bioorg Medic Chem. 2019; 27(10):2090-9. https://doi. org/10.1016/j.bmc.2019.04.004

14. Daly S, Hayden K, Malik I, Porch N, Tang H, et al. Unprecedented $\mathrm{C}-2$ arylation of indole with diazonium salts: Syntheses of 2,3-disubstituted indoles and their antimicrobial activity. Bioorg Med Chem Lett. 2011;21(16):4720-3. https://doi.org/10.1016/j. bmcl.2011.06.081

15. Sakhuja R, Panda SS, Khanna L, Khurana S, Jain SC Design and synthesis of spirolindole-thiazolidinelspirolindole-pyrans] as antimicrobial agents. Bioorg Med Chem Lett. 2011;21(18):5465-9. https://doi.org/10.1016/j. bmcl.2011.06.121

16. Jain $\mathrm{P}$, Utreja $\mathrm{D}$, Poonam $\mathrm{S}$. An efficacious synthesis of $\mathrm{N}-1 \mathrm{C}-3$ substituted indole derivatives and their antimicrobial studies. Journal of Heterocyclic Chemistry. 2019; 57(1):428-35. https://doi.org/10.1002/jhet.3799

17. Kaur J, Utreja D, Ekta, Nisha J, Shivali S. Recent Developments in the Synthesis and Antimicrobial Activity of Indole and its Derivatives. Curr Org Synth. 2019:16(1):1737. https://doi.org/10.2174/1570179415666181113144939

18. Brasil. Agência Nacional de Vigilância Sanitária (ANVISA). Gerência Geral de Tecnologia em Serviços de Saúde (GGTSS). Gerência de Vigilância e Monitoramento em Serviços de Saúde (GVMSS). Plano Nacional para a Prevenção e o Controle da Resistência Microbiana nos Serviços de Saúde; 2017 [cited 2017 Nov 03]. Available from: http://portal.anvisa.gov. br/documents/33852/271855/Plano+Nacional+pa$\mathrm{ra}+\mathrm{a}+$ Prevenção+e+o+Controle+da+Resistência+Micro$\underline{\text { biana+nos+Serviços+de+Saúde }}$

19. Park SH, Kim JK and Park K. In vitro antimicrobial activities of fusidic acid and retapamulin against mupirocin - and methicillin-resistant Staphylococcus aureus. Ann. Dermatol. 2015; 27: 551-6. https://doi.org/10.5021/ad.2015.27.5.551

\section{Laísa Borges Ferreira}

Master in Agricultural and environmental Microbiology, Institute of Health Sciences, Federal University of Rio Grande do Sul (UFRGS), in Porto Alegre, RS, Brazil. Clinical Research coordinator at Hospital de Clinicas de Porto Alegre, Porto Alegre, RS, Brazil.

\section{Edilma Elayne da Silva}

Master in Chemistry, Federal University of Pernambuco, RE, Brazil. Doctorate Student in Organic chemistry, Institute of Chemistry (IQ), Federal University of Rio Grande do Sul (UFRGS), in Porto Alegre, RS, Brazil.

\section{Silvia Adriana Meyer Lentz}

Master in Agricultural and Environmental Microbiology, Institute of Health Sciences, Federal University of Rio Grande do Sul (UFRGS), in Porto Alegre, RS, Brazil. Doctorate student at in Agricultural and Environmental Microbiology, Institute of Health Sciences, Federal University of Rio Grande do Sul (UFRGS), in Porto Alegre, RS, Brazil.

\section{Juliano Braun de Azeredo}

PhD and Master in Organig Chemistry, Federal University of Santa Catarina (UFSC), in Florianópolis, SC, Brazil. Professor at Organic Chemistry and Pharmacognosy Laboratory, Federal University of Pampa (UNIPAMPA), in Uruguaiana, RS, Brazil.

\section{Antonio Luiz Braga}

PhD and Master in Organig Chemistry, Federal University of São Paulo (UNIFESP), in São Paulo, SP, Brazil. Professor at Chemistry department, Federal University of Santa Catarina (UFSC), in Florianópolis, SC, Brazil.

\section{Michel Mansur Machado}

$\mathrm{PhD}$ in Biological Science, Federal University of Santa Maria (UFSM), in Santa Maria, RS, Brazil. Master in Pharmaceutical Science, Federal University of Santa Maria (UFSM), in Santa Maria, RS, Brazil. Professor at Clinical Immunology and Toxicology Laboratory, Federal University of Pampa (UNIPAMPA), in Uruguaiana, RS, Brazil.

\section{Mario Lettieri Teixeira}

PhD and Master in Molecular and Cellular Biology, Federal University of Rio Grande do Sul (UFRGS), in Porto Alegre, RS, Brazil. Professor at Federal Institute of Santa Catarina, in Concórdia, SC, Brazil. 


\title{
Juliana Caierão
}

PhD in Science, Federal University of Rio de Janeiro (UFRJ), in Rio de Janeiro, RJ, Brazil. Master in Medical Science, Federal University of Health Science of Porto Alegre, in Porto Alegre, RS, Brazil (UFCSPA). Professor at Postgraduate Program in Pharmaceutical Sciences, Federal University of Rio Grande do Sul, in Porto Alegre, RS, Brazil.

\section{Gustavo Pozza Silveira}

Doctor in Chemistry, Federal University of Santa Catarina (UFSC), in Florianópolis, SC, Brazil. Professor at Federal University of Rio Grande do Sul (UFRGS), in Porto Alegre, RS, Brazil.

\section{Andreza Francisco Martins}

Doctor in Medical Science, Federal University of Rio Grande do Sul (UFRGS), in Porto Alegre, RS, Brazil. Master in Pharmaceutical Science, Federal University of Rio Grande do Sul (UFRGS), in Porto Alegre, RS, Brazil. Professor at Federal University of Rio Grande do Sul (UFRGS), in Porto Alegre, RS, Brazil.

\author{
Mailing address \\ Andreza Francisco Martins \\ Universidade Federal do Rio Grande do Sul \\ Instituto de Ciências Básicas da Saúde \\ Sarmento Leite, 500 \\ 90050-170 \\ Porto Alegre, RS, Brazil
}

Os textos deste artigo foram revisados pela Poá Comunicação e submetidos para validação do(s) autor(es) antes da publicação. 